\title{
Addition of free poloxamer 407 to a new gene vector P407-PEI-K12 solution forms a sustained-release in situ hypergel that enhances cell transfection and extends gene expression
}

\author{
HONGMEI SHU ${ }^{1}$, YAGUANG ZHANG ${ }^{1}$, MIN ZHANG $^{1}$, JUNWEN WU ${ }^{1}$, \\ MINGXIAO CUI ${ }^{1}$, KEHAI LIU ${ }^{1}$ and JUN WANG ${ }^{2}$ \\ ${ }^{1}$ Department of Biopharmaceutics, College of Food Science and Technology, Shanghai Ocean University; \\ ${ }^{2}$ Department of Gynaecology and Obstetrics, East Branch, Shanghai Jiao Tong University \\ Affiliated Sixth People's Hospital, Shanghai 201306, P.R. China
}

Received April 13, 2018; Accepted November 29, 2018

DOI: $10.3892 / \mathrm{ol} .2019 .9944$

\begin{abstract}
To address the concern around the efficiency/cytotoxicity ratio and the tumor-targeting effects of polyethylenimine (PEI), is a non-viral gene vector used for the delivery of the cancer therapy gene, poloxamer 407 (P407)-PEI-K12, was synthesized by cross-linking low-molecular weight PEI with P407 and further coupling a bifunctional peptide, K12, which is comprised of the tumor-targeting peptide tLyP-1 and the nuclear localization sequence. Furthermore, the addition of free P407 into the polymer/DNA complex solution produced a temperature-sensitive in situ gel-P407/P407-PEI-K12/DNA complex, which improved the effects of sustained-release gene delivery and transfection efficiency. The specificity, cytotoxicity and gene transfection efficiency of P407-PEI-K12 was investigated in Hela cells in vitro. The polymer efficiently prevented the degradation of plasmid DNA by DNase I and had a marked ability for serum tolerance. Agarose gel electrophoresis revealed that plasmid DNA was efficiently condensed and protected. The higher transfection efficiency of P407-PEI-K12h (the molar ratio of P407-PEI and K12 is 1:10) was achieved with a polymer and plasmid DNA ratio (w/w) of 20:1. The ability of free P407 to promote the transfection of the polymer/DNA complex was high (0.09\%). The half-life of the P407/P407-PEI-K12-h/DNA gel complex was $228 \mathrm{~min}$, and the transfection efficiency of the
\end{abstract}

Correspondence to: Dr Kehai Liu, Department of Biopharmaceutics, College of Food Science and Technology, Shanghai Ocean University, 999 Hucheng Ring Road, Shanghai 201306, P.R. China

E-mail:khliu@shou.edu.cn

Dr Jun Wang, Department of Gynaecology and Obstetrics, East Branch, Shanghai Jiao Tong University Affiliated Sixth People's Hospital, 222 Third Huanhu Road West, Shanghai 201306, P.R. China E-mail: wangjun200408@aliyun.com

Key words: non-viral gene vector, polyethylenimine, poloxamer 407, P407/P407-PEI-K12, transfection efficiency, sustained-release, gels
P407/P407-PEI-K12-h/DNA complex was markedly higher compared to that of the P407-PEI-K12-h/DNA complex at various release times.

\section{Introduction}

Cancer is one of the most serious health-threatening diseases, which is caused by unregulated gene damage and mutations. Research in this area is therefore crucial; gene-targeting cell therapy is already presenting great potential in the treatment of cancer (1). Vectors, including viral and non-viral types, can be used to deliver therapeutic DNA into target cells. Non-viral vectors have recently attracted marked interest because of their unlimited carrying capacity, controllable chemical structure, low toxicity and low levels of induced immune responses (2). Due to its strong cell adhesion and good transfection capacity, polyethylenimine (PEI) is a favorable transgenic non-viral vector $(3,4)$; however, the major drawbacks of PEI are a negative ratio between transfection efficiency and cytotoxicity, and a lack of tumor targeting (5). To overcome these problems, PEI is linked by degradable linkers, including ester, $\beta$-aminoester and disulphide, to obtain short PEI chains that present higher efficiency and lower cytotoxicity (6). In the present study, low molecular weight (LMW) PEI was cross-linked with P407, in order to synthesize the PEI-derivate P407-PEI, which may have a high transfection efficiency and may degrade into low cytotoxic LMW PEI. TLyp-1 peptide is a tumor-homing and penetrating peptide that contains the $(\mathrm{R} / \mathrm{K}) \mathrm{XX}(\mathrm{R} / \mathrm{K})$ motif. It has been reported that tLyp-1 improves the penetration of nanoparticles across the cell membrane (7). In addition, the nuclear localization sequence (NLS) is an array of proteins that promotes DNA delivery into the nucleus (8). In the present study, a novel chimeric peptide tLyP-1-NLS (Pro-Lys-Lys-Ly s-Arg-Lys-Val-Cys-Gly-Asp-Lys-Arg-Trp-Arg), named K12, was synthesized by combining the tumor-targeting peptide tLyP-1 and the NLS; K12 is expected to exhibit highly selective expression and promote the delivery of DNA complexes into the nucleus. In the present study, P407-PEI-K12 was synthesized by cross-linking the peptide K12 with P407-PEI; P407-PEI-K12 may improve tumor targeting and increase 
cellular uptake of genes. It has previously been demonstrated that a similar vector, P123-PEI-R11, has a high transfection efficiency with moderate cytotoxicity (9).

In the present study, free P407 was added to the P407-PEI-K12 solution to form a temperature-sensitive type of in-situ gel-P407/P407-PEI-K12/DNA complex, in order to achieve sustained release of P407-PEI-K12/DNA complex and increase transfection efficiency.

Temperature-sensitive polymers have been widely used to develop temperature-sensitive vehicles for drug delivery. Poloxamers are triblock copolymers comprised of two hydrophilic end blocks of polyethylene oxide (PEO) and a central hydrophobic block of polypropylene oxide (PPO). The length of the polymer block highly affects the nonionic and structural arrangement of PEO-PPO-PEO, which has an amphiphilic and thermoresponsive character (10). P407, a nonionic thermosensitive, poly(ethylene oxide)-block-poly(propylene oxide)-block-poly (ethylene oxide) copolymer, exists in liquid and gel states at $4-5^{\circ} \mathrm{C}$ and high temperatures, respectively, and turns from a low viscosity solution into a gel at a concentration of $18 \%(\mathrm{w} / \mathrm{v})(11-13)$. Due to its thermogelation properties, low toxicity and good biocompatibility; P407 may therefore represent a novel drug-controlled release carrier (14). Previous studies have also demonstrated the extended and localized viral gene expression of $\mathrm{P} 407$ in vivo $(15,16)$. The $\mathrm{P} 407 / \mathrm{CA} / \mathrm{GA}$ gel remains in a gel state in the medium for $>1$ month (17). Analysis of $\mathrm{P} 407$ and poloxamer 188-based thermoresponsive ketorolac tromethamine in situ gel preparations has confirmed that such gels are able to prolong and control drug release (18).

Not only does $\mathrm{P} 407$ possess thermogelation properties, but it also enhances cell transfection. Previous studies have reported that free poloxamers accelerate recombinant adeno-associated virus-mediated transgene expression in various types of tissue and improve transfection efficiency by minimizing cell injury $(19,20)$. Novel strategies that increase the gene contact time via formation of in situ gels may allow more stable gene expression. In the present study, P407-PEI-K12 reduced PEI-induced cytotoxicity, improved tumor targeting and upregulated gene cellular uptake. Furthermore, free P407, a temperature-sensitive type in situ gel with active tumor targeting and therapeutic efficiency enhancement, was added into P407-PEI-K12 solution, in order to form a novel hydrogel complex leading to stable released gene expression, enhanced cell transfection and prolonged gene expression.

\section{Materials and methods}

Materials. PEI (2 kDa, PEI 25 kDa), N-succinimidyl-4 -(N-maleimido-methyl) cyclohexane-1-carboxylate (SMCC), 3-(4,5-dimethylthiazol-2-yl)-2,5-diphenyl tetrazolium bromide (MTT), Ethidium bromide and DNase I were purchased from Sigma-Aldrich (Merck KGaA, Darmstadt, Germany). Sephadex G-25 and Dulbecco's modified Eagle's medium (DMEM) was provided by Pharmacia (Milton Keynes, UK). Dimethyl sulfoxide (DMSO) and triphosgene were purchased from Shanghai Ouyi Biomedicals Branch Company (Shanghai, China). Ultrafiltration centrifuge tubes were obtained from Shanghai Health and Biological Company (Shanghai, China). P407 (MW $12,600 \mathrm{Da}$ ) was purchased by BASF Corporation (Mount Olive, NJ, USA), K12 (MW 1,699.11 Da) was synthesized by GL
Biochem Ltd. (Shanghai, China). N-hydroxysuccinimide was provided by Shanghai Source Leaf Biotechnology Development Company (Shanghai, China). Toluene, benzene, triethylamine and anhydrous ethanol were provided from Shanghai Ocean University Public Laboratory (Shanghai, China). Hela cells were provided by Shanghai Cell Bank (Shanghai, China). Fetal bovine serum (FBS) and pancreatic enzyme were obtained from Invitrogen (Thermo Fisher Scientific, Inc., Waltham, MA, USA). The bicinchoninic acid (BCA) protein quantitative kit was purchased from Thermo Fisher Scientific, Inc. The purity of the purified and concentrated DNA was determined by measuring ultraviolet absorbance at 260 and $280 \mathrm{~nm}$, respectively. Cell culture lysis reagent (CCLR) was obtained from Promega Corporation (Madison, WI, USA). A luciferase assay system used for the in vitro transfection assay and a pGL3-Control vector with SV-40 promoter and enhancer driving firefly (Photinus pyralis) luciferase were obtained from Promega Corporation. The plasmid-encoding enhanced green fluorescent protein (pEGFP-N2) was kindly provided by the Institute of Life Science and Technology at Tongji University (Shanghai, China). Plasmid pEGFP-N2 and pGL3-Control were obtained from Promega Corporation. The plasmids were amplified using Escherichia coli DH5 $\alpha$ and prepared using the Qiangen End-free Plasmid Mega kit provided by the Qiagen GmbH (Hilden, Germany).

Synthesis of P407-PEI. To produce P407-PEI, P470 was initially activated. To do so, P407 (0.01 mmol) was dried twice in a vacuum by co-evaporation in the presence of anhydrous toluene at $40^{\circ} \mathrm{C}$. It was then dissolved in toluene/dichloromethane $(3: 1,40 \mathrm{ml})$ and treated with bis-(trichloromethyl)-carbonate $(0.356 \mathrm{~g}, 1.2 \mathrm{mmol})$ overnight. After solution evaporation, the residue was suspended in toluene/dichloromethane $(2: 1,30 \mathrm{ml})$ and treated with solid $\mathrm{N}$-hydroxysuccinimide $(0.240 \mathrm{~g}, 2.0 \mathrm{mmol})$, followed by anhydrous triethylamine $(0.28 \mathrm{ml}, 2.0 \mathrm{mmol})$. After $4 \mathrm{~h}$ stirring, the solution was filtered and evaporated. The residue was collected, which represented activated P407.

Activated P407 (0.010 mmol) was added to $10 \mathrm{ml}$ anhydrous ethanol to obtain solution A, and 5, 10 and 20-fold molar dehydrated PEI $2 \mathrm{kDa}(0.010 \mathrm{mmol})$ was added to $20 \mathrm{ml}$ anhydrous dichloromethane to obtain solution B. Subsequently, solutions $\mathrm{A}$ and $\mathrm{B}$ were added to $10 \mathrm{ml}$ anhydrous dichloromethane and the mixture was stirred overnight at room temperature. P407-PEI-5, P407-PEI-10 and P407-PEI-20 were eventually obtained with a molar ratio of PEI/P407 of 5:1, 10:1 and 20:1, respectively. The polymer was dialyzed for 2 days at $4^{\circ} \mathrm{C}$, lyophilized and stored at $-20^{\circ} \mathrm{C}$.

Mass spectrometry and High-performance liquid of K12. Parameters for MS analysis were ESI ion source, probe bias of $+4.5 \mathrm{KV}$, the rate of Nebulizer Gas Flow is $1.5 \mathrm{~L} / \mathrm{min}, \mathrm{CDL}$ of $-20.0 \mathrm{~V}$, the temperature of $\mathrm{CDL}$ is $250^{\circ} \mathrm{C}$, the rate of T.Flow is $0.2 \mathrm{ml} / \mathrm{min}$, the Block temperature is 200 urce, probe bias of $+4.5 \mathrm{KV}$, the ratKromasil $\mathrm{C} 18$ column $(4.6 \times 250 \mathrm{~mm}$, $5 \mu \mathrm{m}$ ) was selected as a chromatographic column. Gradient elution was performed using acetonitrile (A) and $\mathrm{H}_{2} \mathrm{O}(\mathrm{B})$ with the following linear gradient combinations: $10 \%$ A-90\% B (0-0.01 min), 35\% A-65\% B (0.01-25 min), 100\% A-0\% B (25-25.1 min). The column temperature was $25^{\circ} \mathrm{C}$. The flow 
rate was $1.0 \mathrm{ml} / \mathrm{min}$, and $20 \mu 1$ samples were injected. The detection wavelength was $220 \mathrm{~nm}$.

Conjugation of P407-PEI with K12. Polymer P407-PEI was conjugated with the K12 peptides using SMCC as a crosslinker (21). SMCC solution $(3.33 \mathrm{mg} / \mathrm{ml})$ was added to the P407-PEI solution $(10 \mathrm{mg} / \mathrm{ml})$ at the optimal molar ratio of 10:1 and gently stirred for $30 \mathrm{~min}$ at room temperature. The non-conjugated SMCC was removed by gel chromatography (Sephadex G-25; Pharmacia, Milton Keynes, UK). Thus, $\mathrm{N}$-hydroxysuccinimide (NHS) eaters of SMCC have reacted with primary amines of P407-PEI to form amide bonds and produce the maleimide-activated P407-PEI. Subsequently, $10 \mathrm{mg} / \mathrm{ml} \mathrm{K12}$ was mixed with the maleimide-activated P407-PEI at a molar ratio of 2:1 and 10:1, respectively, and then stirred in the dark overnight at $4^{\circ} \mathrm{C}$ prior to lyophilization. Two polymers were obtained and 2:1 was used to obtain P407-PEI-K12-1 and 10:1 was used to obtain P407-PEI-K12-h. P407-PEI-K12-1 and P407-PEI-K12-h were eventually dissolved in deuterium oxide, and a ${ }^{1} \mathrm{H}$-nuclear magnetic resonance (NMR) spectral analysis was carried out at room temperature. First, $10 \mathrm{mg}$ of P407-PEI and P407-PEI-K12 was dissolved in $0.6 \mathrm{ml}$ of deuterium oxide $\left(\mathrm{D}_{2} \mathrm{O}\right)$ in a nuclear magnetic resonance (NMR) tube, and the ${ }^{1} \mathrm{H}$ NMR spectrum was recorded using a $300-\mathrm{mHz}$ spectrometer at room temperature. The MW and distribution of the polymer was determined by gel permeation chromatography with multiangle laser light scattering and a laser wavelength of $690 \mathrm{~nm}$, using a TSK-GEL G5000PWXL column (temperature $40^{\circ} \mathrm{C}$ ) operated at a flow rate of $0.4 \mathrm{ml}$ per min. Ammonium acetate $0.2 \mathrm{M}$ was used as the mobile phase.

Buffering capacity of P407-PEI-K12. The newly synthesized polymer P407-PEI-K12 was prepared in $50 \mathrm{ml}$ flasks $(0.2 \mathrm{mg} / \mathrm{ml}$, $30 \mathrm{ml}$ ), and the $\mathrm{pH}$ was adjusted to 10.0 with $0.1 \mathrm{M} \mathrm{HCl}$.

Particle size, zeta potential measurement and morphologic observation. Charge ratio (w/w) of the P407-PEI-K12/DNA complex was expressed as the ratio of P407-PEI-K12 and DNA weights. The complex was formed by self-assembly after mixing the Plasmid DNA and polymer solutions $(0.1 \mathrm{M}$ PBS, pH 7.4) at a desired charge ratio. The complex prepared was then incubated for $30 \mathrm{~min}$ at $37^{\circ} \mathrm{C}$. Particle size and zeta potential of the polymer/DNA complex were then measured in PBS and at room temperature using an electrophoretic light-scattering spectrophotometer with a $90^{\circ}$ scattering angle.

Oncethecomplexes P407-PEI-K12 andP407-PEI-K12/DNA were synthesized, a drop of the complex solution was placed on a copper grid. The sample was natural air-dried and the splutter coating was spray-gold and the morphological characteristics of P407-PEI-K12 and P407-PEI-K12/DNA were observed by scanning electron microscopy.

Agarose gel retardation assay. In order to examine the ability of the polymers to condense plasmid DNA, various w/w ratios of polymer/DNA complexes were prepared. Briefly, 10X loading buffer $(1 \mu \mathrm{l})$ was added to $5 \mu \mathrm{l}$ P407-PEI-K12/DNA complex solution. A total of $10 \mu \mathrm{l}$ sample was then loaded onto $1 \%(\mathrm{w} / \mathrm{v})$ the gel and electrophoresis was run for $40 \mathrm{~min}$ at $120 \mathrm{~V}$. The gel was eventually stained with ethidium bromide for $\sim 20 \mathrm{~min}$ at room temperature and illuminated on an ultraviolet illuminator to locate DNA.

Resistance to DNase I digestion and serum. DNase I solution was added to $50 \mu \mathrm{l}$ complex solution in $1.5 \mathrm{ml}$ tubes and incubated at $37^{\circ} \mathrm{C}$ for $30 \mathrm{~min}$. The range of DNase I doses per Plasmid DNA (pDNA) weight unit was between 3 and $72 \mathrm{U}$ DNase I $\mu$ g DNA. Subsequently, $2 \mu 1250$ mM EDTA solution was added to each tube and incubated at room temperature for $10 \mathrm{~min}$ to inactivate DNase I. Then, $6 \mu 110 \mathrm{mg} / \mathrm{ml}$ sodium heparin was added to each tube and incubated at room temperature for $2 \mathrm{~h}$ to completely dissociate the complex. Agarose gel electrophoresis was performed as previously described to analyze the stability of the complex to DNase I digestion. In addition, various concentrations of FBS (10 $\mu \mathrm{l}$ containing 10 , 25 and $50 \%$ serum) were added to the complex solution and incubated at $37^{\circ} \mathrm{C}$ for $60 \mathrm{~min}$. The sensitivity of P407-PEI-K12 to serum was also determined by agarose gel electrophoresis.

Cytotoxicity assay. The cytotoxicity of P407-PEI-K12 was measured by MTT assay. Hela cells were seeded at a density of 5,000 cells per well in $200 \mu \mathrm{l}$ growth medium (DMEM) supplemented with $10 \%$ FBS in a 96-well plate and incubated for $48 \mathrm{~h}$ at $37^{\circ} \mathrm{C}$ in a humidified incubator containing $5 \% \mathrm{CO}_{2}$. The culture medium was replaced with $200 \mu \mathrm{l}$ serum-free media with increasing concentrations of P407-PEI-K12 $(4,8,16,24$ and $32 \mu \mathrm{l} / \mathrm{ml})$. After $24 \mathrm{~h}$ incubation at $37^{\circ} \mathrm{C}$ in a humidified incubator containing $5 \% \mathrm{CO}_{2}$, medium was replaced with $20 \mu 15 \mathrm{mg} / \mathrm{ml}$ sterilized MTT solution and $180 \mu \mathrm{l}$ fresh growth medium and maintained at $37^{\circ} \mathrm{C}$ for $4 \mathrm{~h}$. Subsequently, the MTT/growth medium was replaced with $150 \mu \mathrm{l}$ DMSO and incubated for $10 \mathrm{~min}$ at room temperature. The absorbance value at $570 \mathrm{~nm}$ was measured using an ELISA plate reader with background subtraction. Cell viability was calculated with the following equation: Cell viability $(\%)=($ Absorbance of cells treated with nanoparticles-Absorbance of free medium alone)/(Absorbance of control untreated cells-Absorbance of free medium alone) x 100 .

\section{Gel preparation and determination of release rate}

Preparation of $P 407 \mathrm{gel}$ and determination of the release rate of P407 gel. P407 solutions (20-23\%) were prepared in $0.1 \mathrm{M}$ PBS at $4^{\circ} \mathrm{C}$. Firstly, the glass vial weight was recorded. P407 solution $(20 \%, 2 \mathrm{~g})$ was added to the vial and heated at $37^{\circ} \mathrm{C}$ in a water bath, to allow the formation of a hydrogel. The weights of the vial and the gel were recorded. Subsequently, $1 \mathrm{ml}$ PBS was added to the vial containing the P407 hydrogel. After $40 \mathrm{~min}$, the PBS containing the released P407 was pipetted out from the vial, and the weight of the vial with the unreleased gel was recorded. Then, $1 \mathrm{ml}$ PBS was added again, and aliquots of the same PBS were pipetted out at regular intervals for $\sim 40 \mathrm{~min}$, before assessing the weight of the bottle with the unreleased gel. The amount of gel released was determined at the same intervals and the gel release rate was calculated. The same method was used to determine the release rate of 21, 22 and 23\% P407 gels.

Synthesis of P407/P407-PEI-K12-h/DNA complex gel. The freshly prepared P407-PEI-K12-h/DNA complex was mixed at $4^{\circ} \mathrm{C}$, with free $\mathrm{P} 407$ (mass ratio $8.75: 1$ and $21 \%$ ) to form a P407/P407-PEI-K12-h/DNA complex solution. 
DeterminationofthereleaserateofP407/P407-PEI-K12-h/DNA complex gel. Firstly, the glass vial weight was recorded. Approximately 2 g P407/P407-PEI-K12-h/DNA solution was added to the vial kept and heated at $37^{\circ} \mathrm{C}$ in a water bath, to allow the formation of the hydrogel; the vial weight was then recorded. Subsequently, $1 \mathrm{ml}$ serum-free medium was added to the hydrogel and heated in a water bath at $37^{\circ} \mathrm{C}$. After $40 \mathrm{~min}$, the release medium containing the released polymer/DNA complex was removed from the vial, and the weight of the vial containing the unreleased gel was recorded. Then, $1 \mathrm{ml}$ serum-free medium was added repeatedly in the vial and removed at regular intervals for $\sim 40 \mathrm{~min}$ prior to calculating the gel release rate.

\section{In vitro gene transfection}

In vitro gene transfection of P407-PEI-K12/DNA complex. The transfection efficiency qualitative and quantitative of P407-PEI-K12 was measured using the plasmid pEGFP-N2 and pGL3-Control, respectively, in Hela cells. A total of $1 \times 10^{5}$ Hela cells were cultured in a 24-well plate for $18-24 \mathrm{~h}$ with $500 \mu \mathrm{l}$ DMEM containing 10\% FBS, in order to reach $80 \%$ confluence. Culture medium was then replaced with $400 \mu 1$ serum-free medium and $100 \mu 1$ freshly prepared P407-PEI-K12/DNA solution containing $2.5 \mu \mathrm{g}$ plasmid pEGFP-N2 or pGL3-Control at various weight ratios $(5,10$, $20,30)$. The cells were incubated at $37^{\circ} \mathrm{C}$ with $5 \% \mathrm{CO}_{2}$ for $4 \mathrm{~h}$. After $4 \mathrm{~h}$, culture medium was replaced with $500 \mu \mathrm{l}$ medium containing $10 \% \mathrm{FBS}$ and incubated at $37^{\circ} \mathrm{C}$ with $5 \% \mathrm{CO}_{2}$ for $48 \mathrm{~h}$. The pEGFP-N2 expression was observed under an inverted fluorescence microscope.

In order to evaluate the transfection effect quantitatively using plasmid pGL3-Control, the luciferase assay was carried out according to the manufacturer's protocol. Culture medium was replaced with $100 \mu 1$ cell culture lysis reagent (CCLR) and stirred for $30 \mathrm{~min}$ at room temperature. Luciferase activity was measured with a luminometer (Turner Designs Luminometer Model TD-20/20; Promega Corporation, Madison, WI, USA). BCA protein assay kit was used to measure protein contents and transfection efficiency for the pGL3-Control. Results were expressed as relative light units (RLUs) against the corresponding protein contents.

In vitro gene transfection of P407-PEI-K12/DNA complex with various concentrations of free P407. After harvesting with $0.25 \%$ trypsin, the cells at a density of $1 \times 10^{5}$ cells per well were seeded into 24 -well plates at $37^{\circ} \mathrm{C}$ with $5 \% \mathrm{CO}_{2}$. Culture medium was replaced with $400 \mu 1$ serum-free medium containing free P407 and $100 \mu$ freshly prepared solution of the polymer/DNA at various concentrations $(0,0.06,0.09$ or $0.12 \%$ ) and containing $2.5 \mu \mathrm{g}$ plasmid pGL3-Control. The cells were incubated at $37^{\circ} \mathrm{C}$ with $5 \% \mathrm{CO}_{2}$ for $4 \mathrm{~h}$. After $4 \mathrm{~h}$, culture medium was replaced with $500 \mu 1$ medium containing $10 \% \mathrm{FBS}$ and incubated at $37^{\circ} \mathrm{C}$ with $5 \% \mathrm{CO}_{2}$ for $48 \mathrm{~h}$. Culture medium was then replaced with $100 \mu \mathrm{l}$ CCLR and stirred for $30 \mathrm{~min}$ at room temperature. The data assessment was performed as previously described.

In vitro gene transfection of P407/P407-PEI-K12-h/DNA complex gels at various release times. After cell harvesting with $0.25 \%$ trypsin, cells at a density of $1 \times 10^{5}$ cells per well were seeded into 24 -well plates at $37^{\circ} \mathrm{C}$ with $5 \% \mathrm{CO}_{2}$. Preliminary experiments demonstrated that complex gels were entirely released after $5 \mathrm{~h}$ at $37^{\circ} \mathrm{C}$. The release solutions were then collected at 5, 10,30,60, 120 and $300 \mathrm{~min}$. The P407/P407-PEI-K12-h/DNA complex gel $(2 \mathrm{~g})$ and $1 \mathrm{ml}$ serum-free medium were added in a glass bottle and incubated in a water bath at $37^{\circ} \mathrm{C}$. At different time points, $\sim 100 \mu \mathrm{l}$ release solution containing free $\mathrm{P} 407$ and the polymers/DNA complex were collected from the bottle $(2.5 \mu \mathrm{g}$ DNA was present in $100 \mu \mathrm{l}$ release solution) and added to $400 \mu \mathrm{l}$ fresh serum-free medium and into a 24 -well plate. The cells were incubated at $37^{\circ} \mathrm{C}$ with $5 \% \mathrm{CO}_{2}$ for $4 \mathrm{~h}$. After $4 \mathrm{~h}$ incubation, culture medium was replaced with $500 \mu \mathrm{l}$ culture medium containing $10 \% \mathrm{FBS}$ and incubated at $37^{\circ} \mathrm{C}$ with $5 \% \mathrm{CO}_{2}$ for $48 \mathrm{~h}$. Eventually, culture medium was replaced with $100 \mu \mathrm{l}$ CCLR and the plate was stirred for $30 \mathrm{~min}$ at room temperature. Data assessment was performed as previously described.

Statistical analysis. The data are presented as the means \pm standard deviation. SPSS Statistics 17.0 (SPSS, Chicago, IL, USA) was used to calculate values. Data from two groups were compared using independent sample t-tests, whereas multiple groups were evaluated using one-way analysis of variance followed by Least Significant Difference post hoc tests. The experiment was repeated six times for statistical analysis. $\mathrm{P}<0.05$ was considered to indicate a statistically significant difference.

\section{Results and Discussion}

Characterization of P407-PEI-K12. The PEI derivates of P407-PEI were synthesized by linking PEI ( $2 \mathrm{kDa})$ with P407, which was then conjugated with the bifunctional peptide K12 to prepare a novel non-viral gene delivery vector, P407-PEI-K12 (Fig. 1). The synthesized peptide K12 was analyzed and identified by mass spectrometry and High Performance Liquid Chromatography (Fig. 2A and B). The molecular weight of K12 was 1,699.11 Da with $98.75 \%$ purity. As shown in Fig. 2C, the ${ }^{1} \mathrm{H}-\mathrm{NMR}$ spectrum of P407-PEI was obtained. The $-\mathrm{CH}_{2} \mathrm{CH}_{2} \mathrm{NH}$ - and $-\mathrm{CH}_{2} \mathrm{CH}_{2} \mathrm{O}$-proton peaks appeared at $\delta 2.51-2.7$ and $\delta 3.25 \mathrm{ppm}$, respectively. The proton peaks of P407-PEI-K12 moved toward the lower magnet field compared to those of P407-PEI (Fig. 2D). The- $\mathrm{CH}_{2} \mathrm{CH}_{2} \mathrm{NH}$-proton peaks present in the $\delta 2.51-2.70 \mathrm{ppm}$ region were not found due to K12 attachment (Fig. 2D). These alterations confirmed that the bifunctional peptide K12 had been successfully linked to P407-PEI.

Buffer capacity of P407-PEI-K12. The majority of cationic polymers have a high buffering capacity, which may disrupt endosomes during transfection, thereby facilitating escape of the polymer/DNA complex $(21,22)$. As shown in Fig. 3, the buffering capacity of P407-PEI-K12-1 was slightly higher than P407-PEI-K12-h. Compared with pure water, P407-PEI-K12-1 and P407-PEI-K12-h exhibited a markedly higher buffering capacity at all $\mathrm{pH}$ values, which indicated that the derived polymer could be a potential gene vector.

Particle size, zeta potential and morphologic observation. As demonstrated in Fig. 4A, P407-PEI-K12 with numerous 

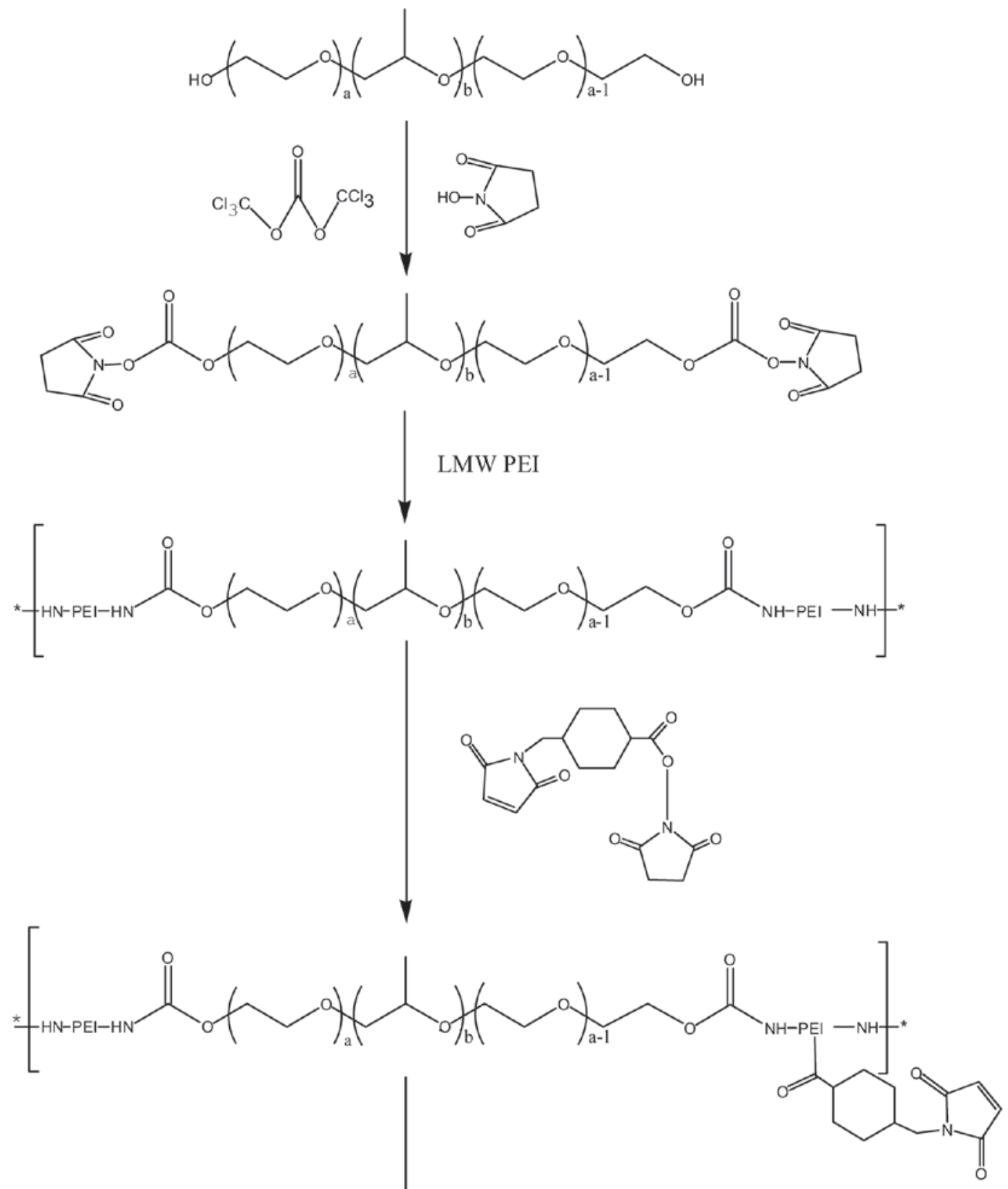

K12

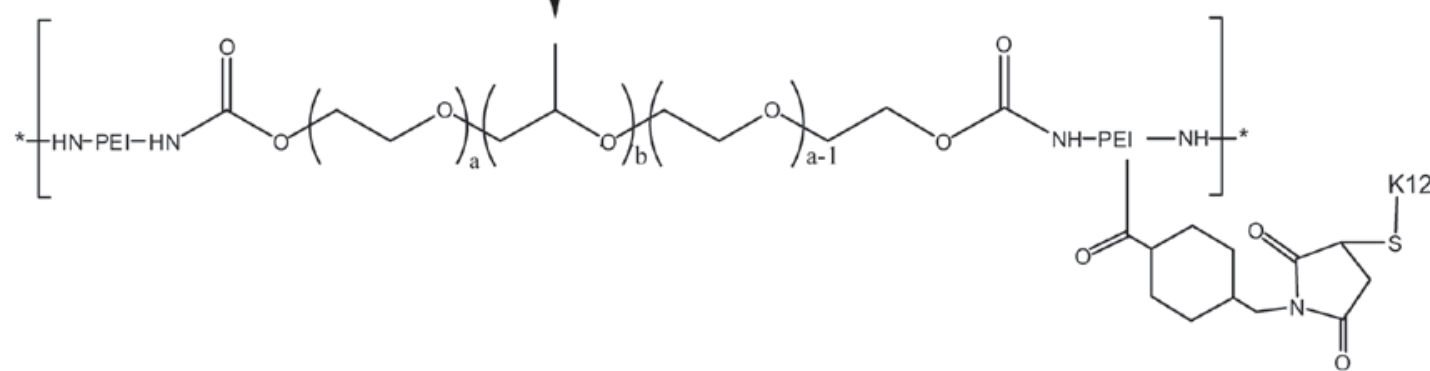

Figure 1. Polymer poloxamer 407-PEI-K12 synthesis. LMW, low molecular weight; PEI, polyethylenimine.

loose branches dispersed uniformly at room temperature, and the particle size ranged between 800 and $1,000 \mathrm{~nm}$. After self-assembly with plasmid DNA, the morphology of P407-PEI-K12/DNA changed to a spherical shape with a particle size distribution of 200-500 nm (Fig. 4B). As presented in Fig. 4C, the sizes of P407-PEI-K12-1/DNA and 

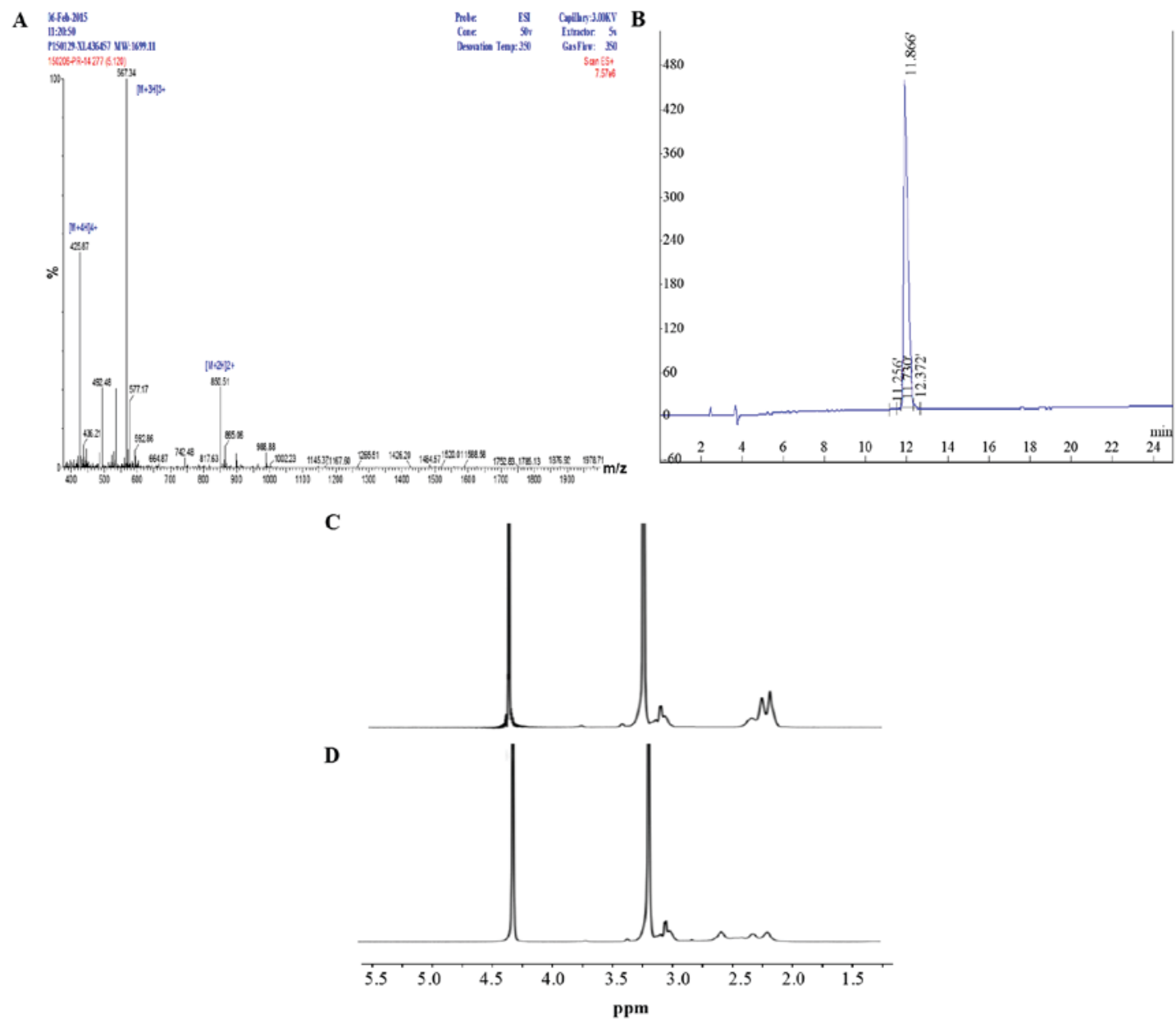

Figure 2. Characterization of P407-PEI-K12. (A) Mass spectrometry report of K12. (B) High-performance liquid chromatography of K12. Representative ${ }^{1} \mathrm{H}-\mathrm{NMR}$ spectra of (C) P407-PEI and (D) P407-PEI-K12 in $\mathrm{D}_{2} \mathrm{O}$ at room temperature. $\mathrm{D}_{2} \mathrm{O}$, deuterium oxide. P407, poloxamer 407; PEI, polyethylenimine.

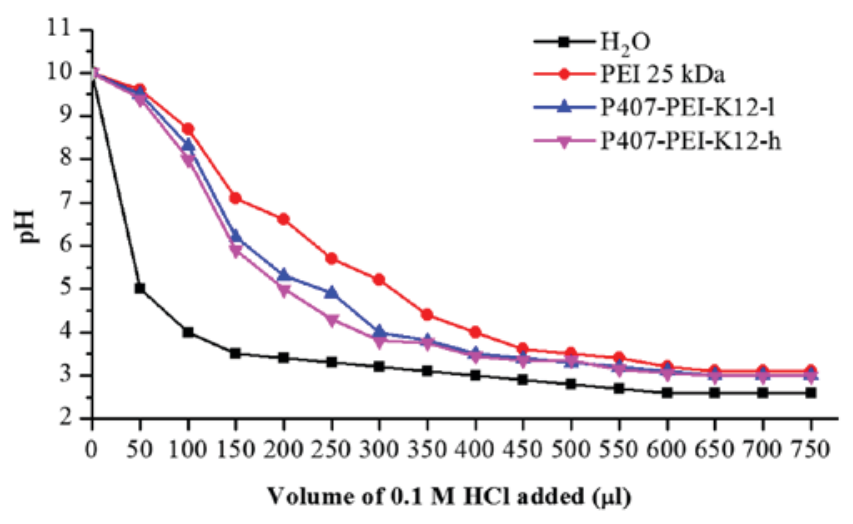

Figure 3. Determination of the buffering capacity of $\mathrm{H}_{2} \mathrm{O}$, PEI $(25 \mathrm{kDa})$, P407-PEI-K12-1 and P407-PEI-K12-h by acid-base titration. The titration curve of water is presented as a control. $\mathrm{HCl}$, hydrochloric acid; $\mathrm{P} 407$, poloxamer 407; PEI, polyethylenimine.

P407-PEI-K12-h/DNA particles decreased with the increasing w/w ratio, and stayed stable between 200 and $500 \mathrm{~nm}$. Previous findings suggested that complexes ranging between 200 and $500 \mathrm{~nm}$ can effectively protect DNA (23). In addition, the complex surface has to be positively charged in order to allow binding to the cell membrane, which is negatively charged. As shown in Fig. 4D, the zeta potential of P407-PEI-K12-1/DNA and P407-PEI-K12-h/DNA increased with increasing w/w ratio. P407-PEI-K12-1/DNA had a higher zeta potential compared to P407-PEI-K12-h/DNA, but their zeta potential was maintained within the range of $5-35 \mathrm{mV}$, which ensures good stability and transferability.

Analysis of the gel electrophoresis block and stability of the polymer/plasmid DNA complex. The DNA condensation capacity of P407-PEI-K12 was assessed by agarose gel electrophoresis. The plasmid DNA movement in the gel was retarded with increasing amount of polymers, since polymers bind to DNA and neutralize charges. When the ratio (w/w) of polymer to DNA exceeds the neutralization component, the complex exhibits a positive charge and stops moving toward the anode. In the present study, P407-PEI-K12-h, P407-PEI-K12-l and P407-PEI-10 were able to effectively condense the DNA at a ratio $(\mathrm{w} / \mathrm{w})$ of $1.2,0.6$ and 0.4 , respectively (Fig. 5A-C). With increasing ratio (w/w) of K12 to $\mathrm{P} 407-\mathrm{PEI}$, the complex to DNA ratio $(\mathrm{w} / \mathrm{w})$ increased in order to efficiently condense DNA, possibly because the peptide shielded a partial positive charge on the surface of the complex. Because of the abundance of DNase I in tissue and blood, DNA degradation by DNase I is a barrier for in vivo gene delivery. Fig. 5D demonstrated that P407-PEI-K12 protected plasmid DNA from degradation by DNase I at various concentrations (0-72 I/ $/ \mathrm{g}$ 
A

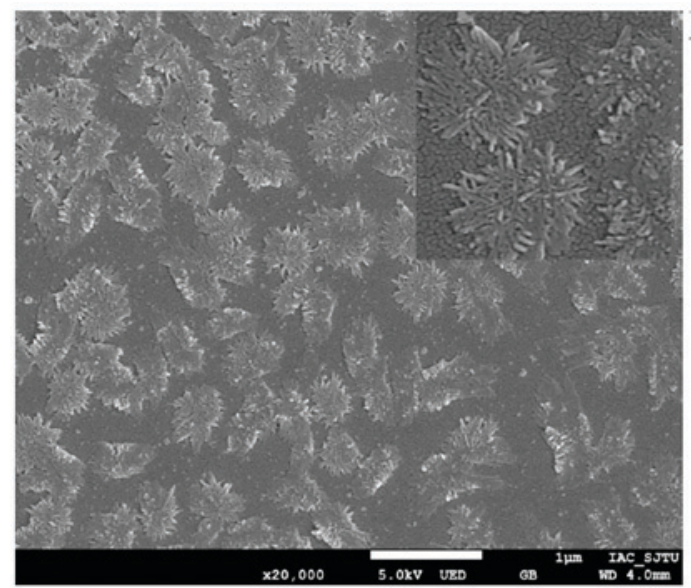

C

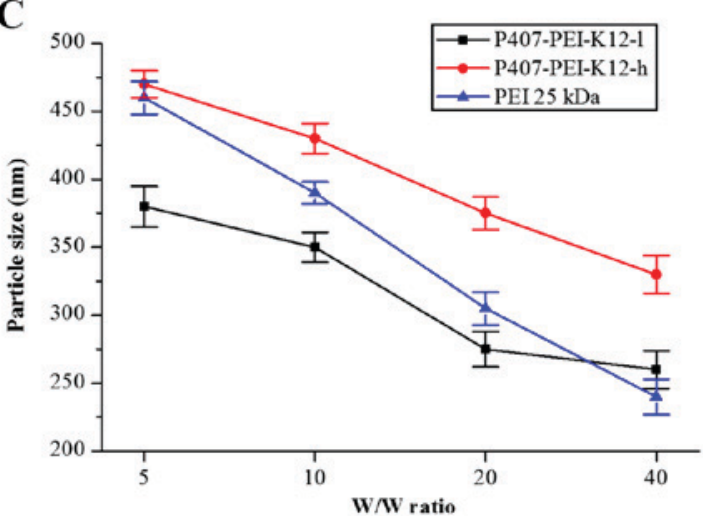

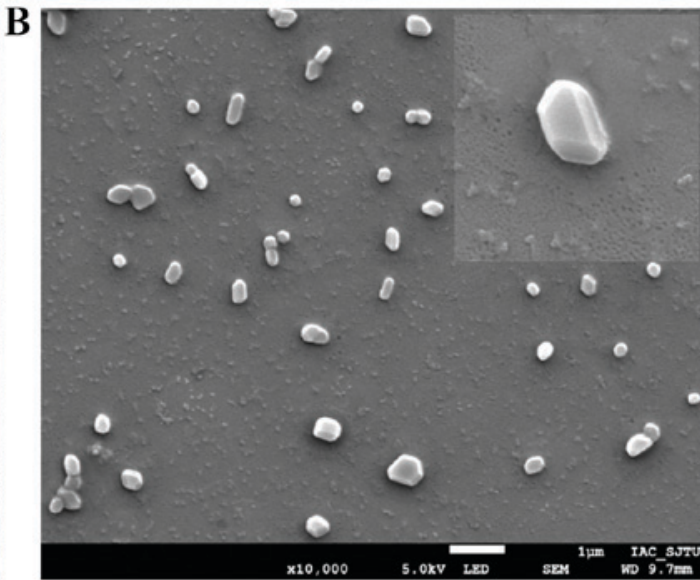

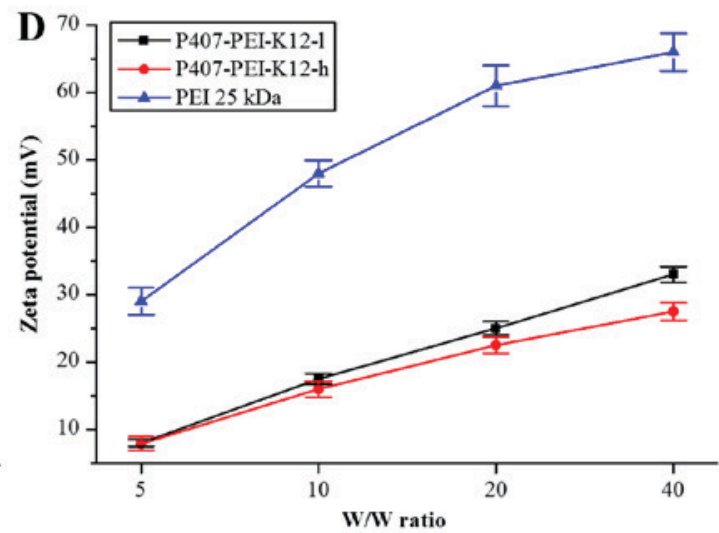

Figure 4. Scanning electron micrograph of (A) P407-PEI-K12 polymer and (B) P407-PEI-K12/DNA complex. (C) Particle size of P407-PEI-K12-1/DNA, P407-PEI-K12-h/DNA,PEI25kDa/DNAatvariouspolymer-to-plasmidDNAw/wratios.(D)Zetapotential(mV)ofP407-PEI-K12-1/DNA,P407-PEI-K12-h/DNA, PEI $25 \mathrm{kDa} / \mathrm{DNA}$ at various polymer-to-pDNA w/w ratios. P407, poloxamer 407; PEI, polyethylenimine.

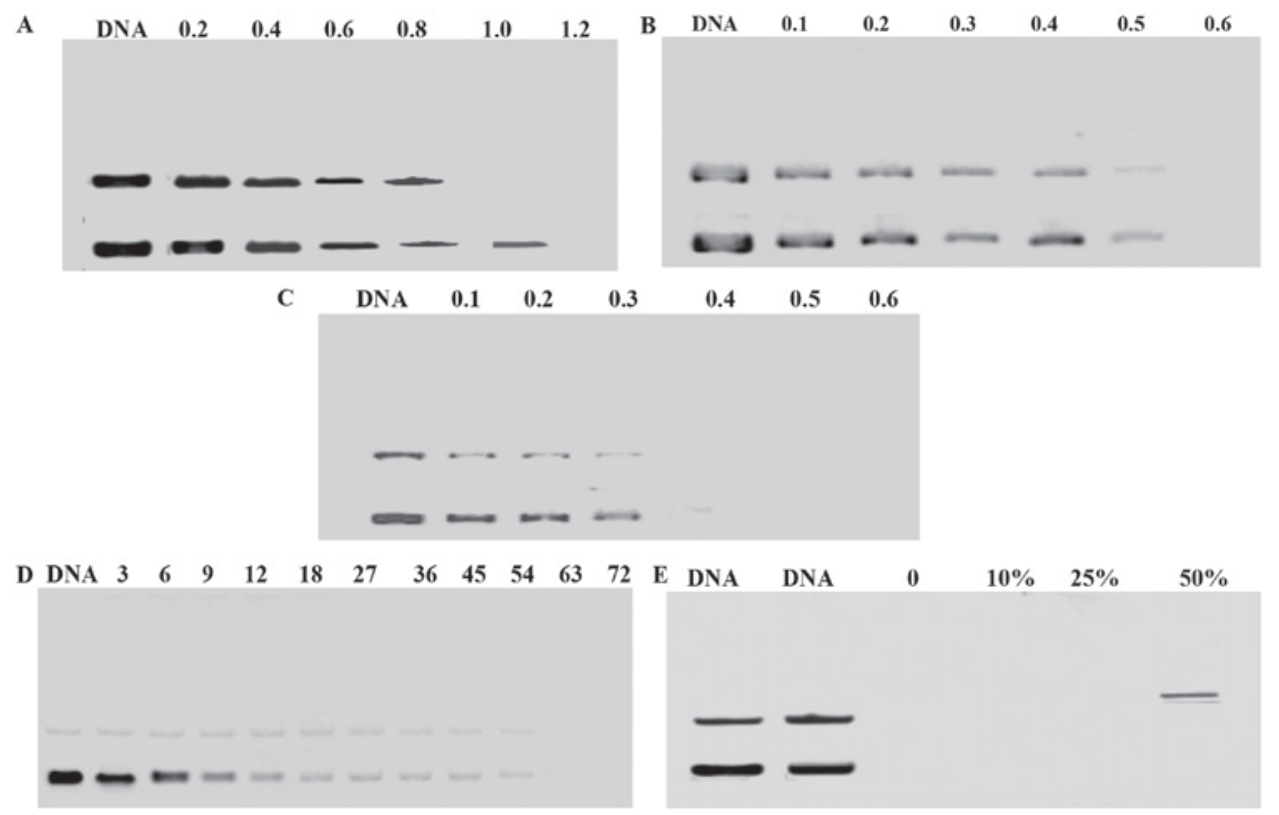

Figure 5. Agarose gel electrophoresis of plasmid DNA and polymer/DNA complex at various w/w ratio: (A) P407-PEI-K12-h, (B) P407-PEI-K12-1 and (C) P407-PEI-10. Protection of P407-PEI-K12 on plasmid DNA: (D) Plasmid DNA protection by P407-PEI-K12 from degradation by DNase I at various concentrations of $0,3,6,9,12,18,27,36,45,54,63$ and 72 DNase I/ $\mu$ g DNA. (E) Plasmid DNA protection by P407-PEI-K12 from degradation by serum at concentrations of $0,10,25$ and $50 \%$. P407, poloxamer 407; PEI, polyethylenimine.

DNA). In reality, a concentration of $0.08 \mathrm{U}$ DNase I/ $\mu \mathrm{g}$ DNA can entirely digest DNA, suggesting that the complex may have a very good tolerance to DNase. The ability of P407-PEI-K12 to protect plasmid DNA from degradation by serum $(0-50 \%)$ is 


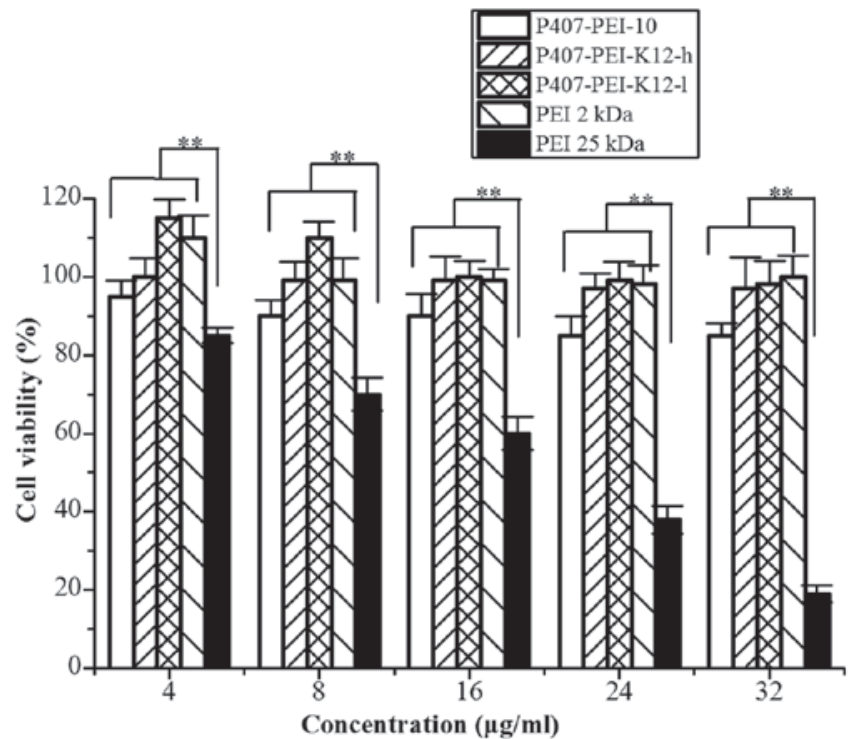

Figure 6. Cytotoxicity of PEI 25 kDa, PEI 2 k Da, P407-PEI-K12-1, P407-PEI-K12-h and P407-PEI-10 at various concentrations in Hela cell lines using MTT assay. The experiment was repeated six times for statistical analysis. Each data point represents the mean \pm standard deviation. $n=6$, ${ }^{* *} \mathrm{P}<0.01$. P407, poloxamer 407; PEI, polyethylenimine.

presented in Fig. 5E, which indicated that P407-PEI-K12 can protect plasmid DNA from degradation, which is indicative of good stability of the polymer. The results suggested that DNA may not be dissociated by serum, suggesting that the complex would remain stable in blood circulation.

Cytotoxicity. A correlation between cytotoxicity and polymer molecular weight was assessed. High molecular weight polymers (which contain more amino groups) compared to LMW polymers induced a higher cytotoxicity. The cytotoxicity of the degradable P407-PEI-K12 was evaluated by the MTT assay using Hela cells treated with PEI (25 kDa). P407-PEI-K12 and PEI 2 kDa exhibited markedly higher cell viability compared with PEI 25 kDa (Fig. 6). P407-PEI-K12 also demonstrated lower cytotoxicity at different concentrations, which indicated that the polymer may be suitable for gene delivery. The reduced cytotoxicity could therefore be attributed to the low amino group density and low toxicity of the building blocks (24). It has previously been demonstrated that the ester bonds contained in P123-PEI-R13 can degrade into poloxamer oligomers and LMW PEI under physiological conditions (5). Similar to P123-PEI-R13, P407-PEI-K12 can be rapidly degraded and excluded from the cell, resulting in reduced cytotoxicity.

In vitro gene transfection of P407-PEI/DNA complex and P407-PEI-K12/DNA complex. All types of P407-PEI exhibited markedly higher transfection efficiency at w/w ratio of 20 and 30 compared with PEI $25 \mathrm{kDa}$, whereas P407-PEI-10 had the highest transfection efficiency compared to the others at a w/w ratio of 20 (Fig. 7). Based on the optimal molar ratio of PEI to P407 of 10:1, peptide K12 was mixed with pretreated $\mathrm{P} 407-\mathrm{PEI}$ at a molar ratio of 2:1 and 10:1 to form P407-PEI-K12-1 and P407-PEI-K12-h, respectively. As shown in Fig. 8A, the transfection efficiency of the P407-PEI-K12-h/DNA and P407-PEI-K12-1/DNA complexes was higher at a weight ratio of 20 . Furthermore,

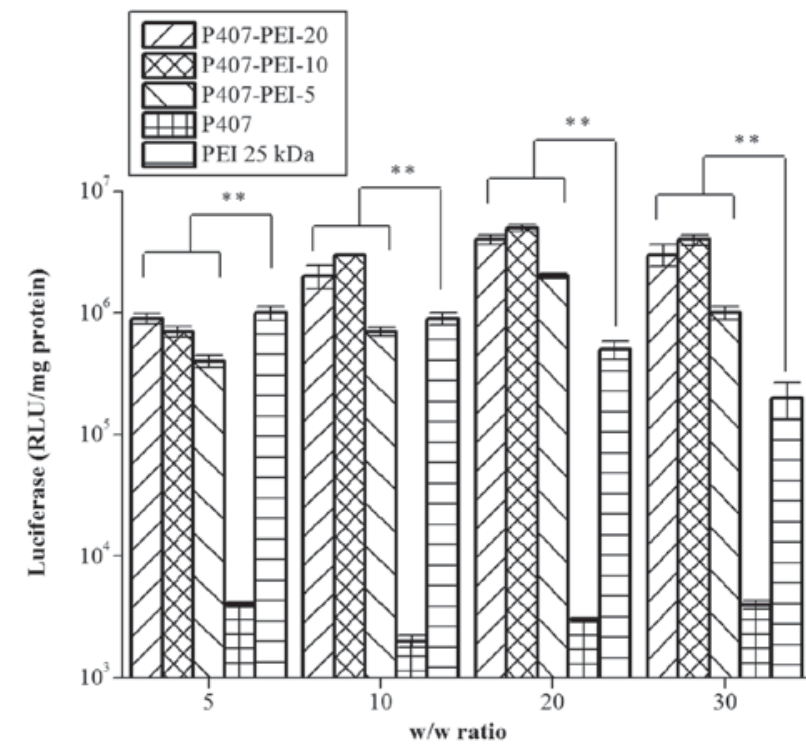

Figure 7. Transfection efficiency of PEI 25 kDa, P407, P407-PEI-5, P407-PEI-10 and P407-PEI-20 in Hela cells. The experiment was repeated six times for statistical analysis. Each data point represents the mean \pm deviation. $\mathrm{n}=6,{ }^{* *} \mathrm{P}<0.01$. P407, poloxamer 407; PEI, polyethylenimine; RLU, relative light unit.

P407-PEI-K12-h/DNA and P407-PEI-K12-1/DNA complexes exhibited maximal transfection efficiency when the weight ratio of polymer to DNA was 20 (Fig. 8B). The gene transferability of all P407-PEI-K12/DNA complexes was higher compared to PEI $25 \mathrm{kDa}$, whereas the P407-PEI-K12-h/DNA complex exhibited the highest luciferase expression level. In addition, the P407-PEI-K12/DNA complex presented a higher gene transfection than P407-PEI-10/DNA complex at optimal conditions, suggesting that the functional peptide K12 may be necessary to modify P407-PEI for enhancing the transfection efficiency of the complex in vitro. Furthermore, the P407-PEI-K12-h/DNA complex had a higher gene transfection than P407-PEI-K12-1/DNA complex at optimal conditions, which implied that the transfection efficiency of the P407-PEI-K12/DNA complex was increased with the rising rates of K12. Furthermore, not only did the K12 peptide allowed cell targeting of P407-PEI-K12/DNA, but it also facilitated the cellular transport.

In vitro gene transfection of P407-PEI-K12/DNA complex with various concentrations of free P407. The P407-PEI-K12-h/DNA complex presented higher gene transfection than the P407-PEI-K12-1/DNA complex with free P407 ranging between 0 and $0.12 \%$ (Fig. 9). The results further revealed that addition of free P407 into P407-PEI-K12/DNA complex solution may have a good effect on gene transfection, whereas P407-PEI-K12-h/DNA complex exhibited higher transfection efficiency compared with P407-PEI-K12-1/DNA complex with same concentrations of free P407. In addition, transfection efficiency was significantly enhanced by $0.09 \%$ free P407, showing that complex solution with the free P407 of $0.09 \%$ have the largest effect.

Release profile of P407 gel and P407/P407-PEI-K12-h/DNA complex gel. Free $\mathrm{P} 407$ can form a gel at concentrations ranging 
A

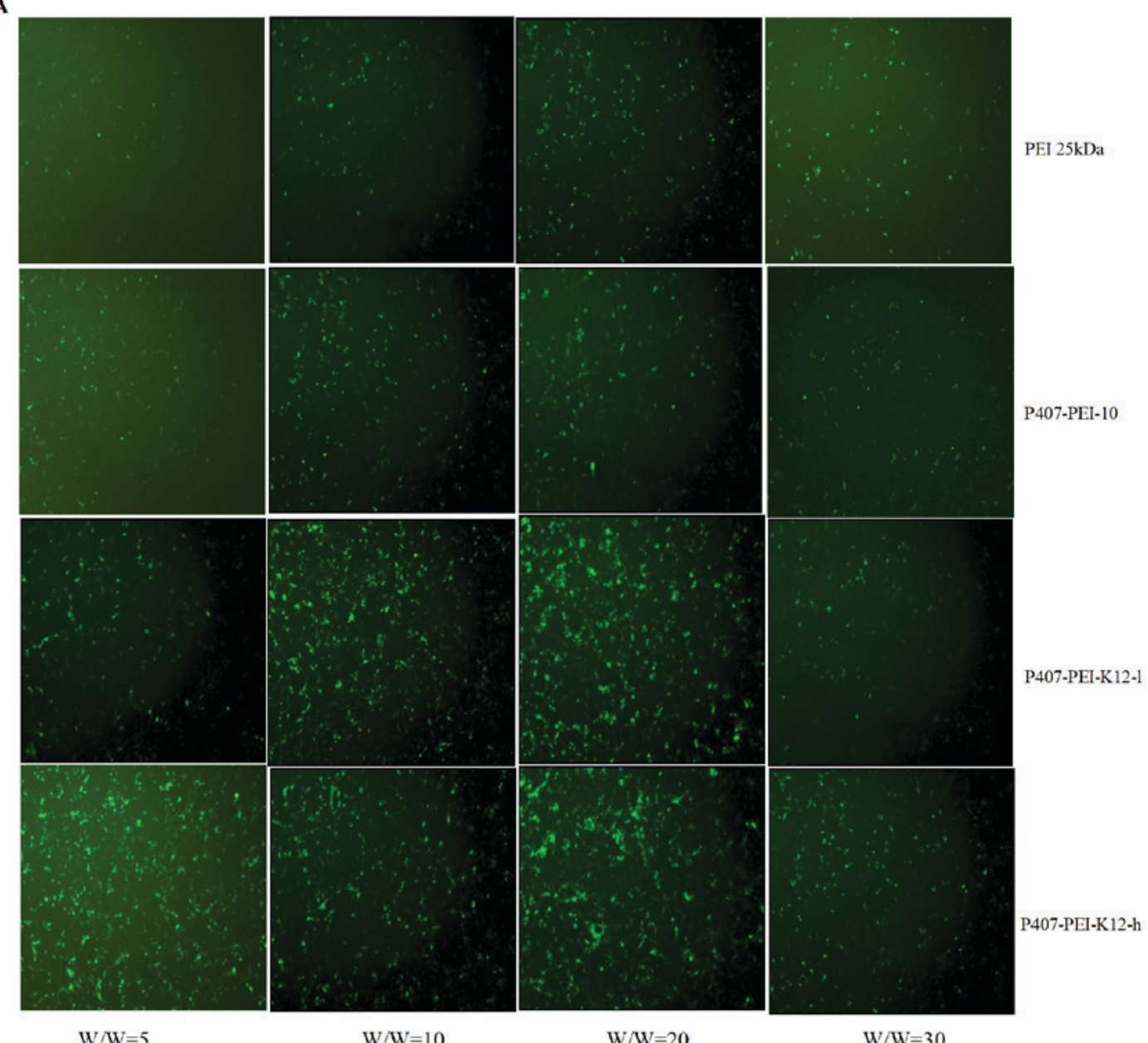

B

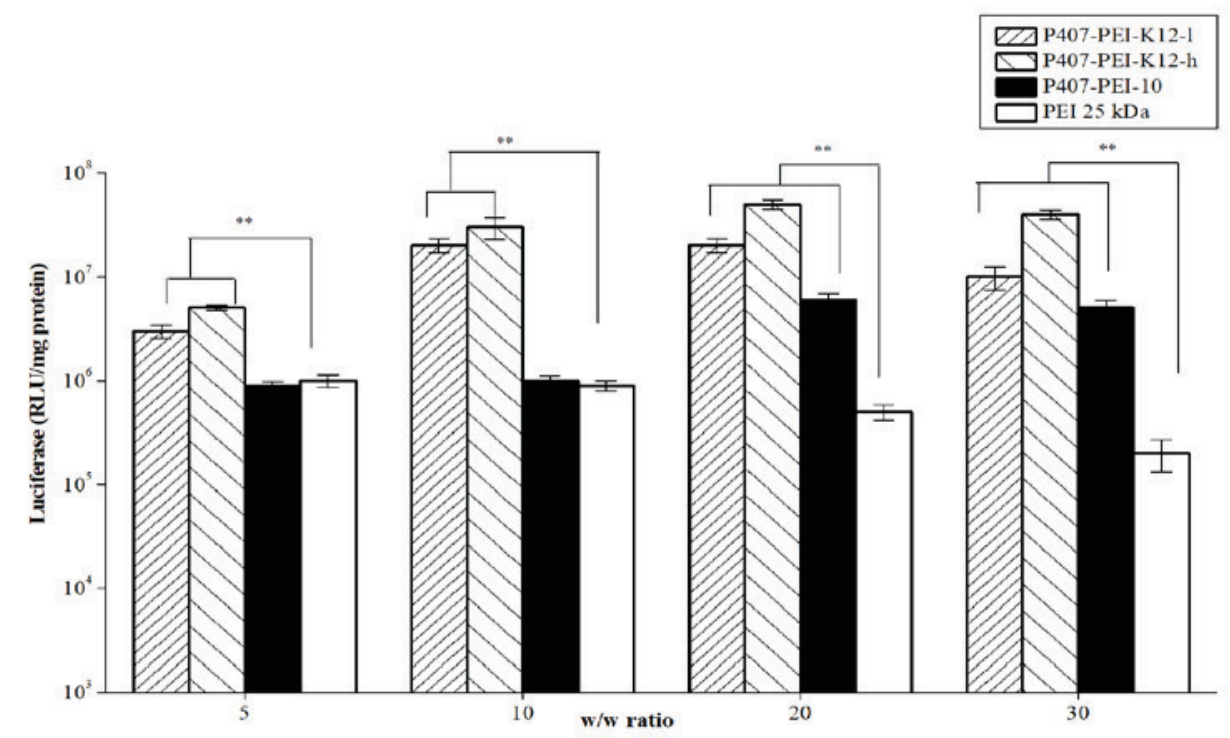

Figure 8. (A) pEGFP-N2 reporter gene transfection in Hela cells by PEI $25 \mathrm{kDa}, \mathrm{P} 407-\mathrm{PEI}-10$, P407-PEI-K12-1 (molar ratio of PEI with P407 was 2:1) and P407-PEI-K12-h (molar ratio of PEI with P407 was 10:1) in 24-well plate. (B) Transfection efficiency of pGL3-Control by PEI 25 kDa, P407-PEI-10, P407-PEI-K12-1, P407-PEI-K12-h in Hela cells. The experiment was repeated six times for statistical analysis. Each data point represents the mean \pm standard deviation. $n=6,{ }^{* * *} \mathrm{P}<0.01$. pEGFP-N2, green fluorescent protein; P407, poloxamer 407; PEI, polyethylenimine; RLU, relative light unit.

between 20 and $25 \%$ (25). In the pre-experiment, it was revealed that gel formation was achieved at concentrations of $20-23 \%$. As presented in Fig. 10A, the release rate gradually decreased with increasing concentrations of free P407. In addition, the half-life of the P407 gel was 213, 222, 236, and $259 \mathrm{~min}$, at 20, 21, 22 and 23\%, respectively, suggesting that all P407 


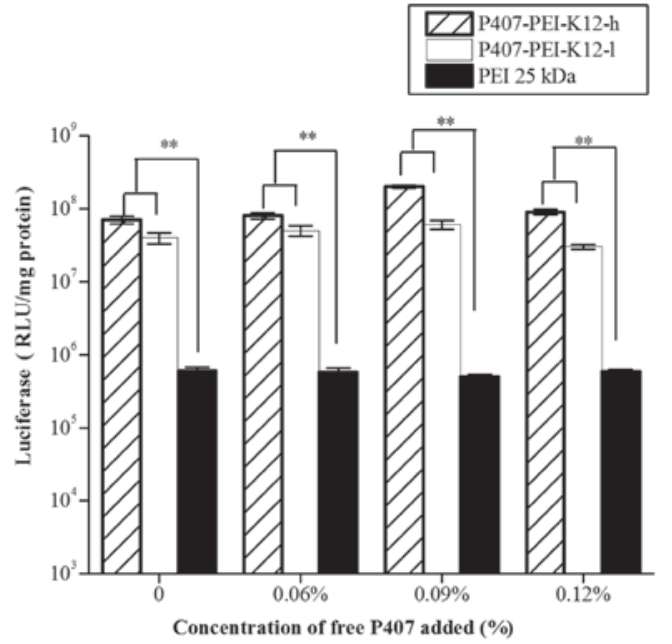

Figure 9. Transfection efficiency of P407-PEI-K12-1, P407-PEI-K12-h and PEI $25 \mathrm{kDa}$ in Hela cells with various concentration of free P407 added (0-0.12\%). The optimal molar ratio of PEI with P407 was maintained at 10:1 with a (polymer/plasmid DNA) w/w ratio of 20 . The experiment was repeated six times for statistical analysis. Each data point represents the mean \pm standard deviation. $\mathrm{n}=6,{ }^{* *} \mathrm{P}<0.01$. $\mathrm{P} 407$, poloxamer 407; PEI, polyethylenimine; RLU, relative light unit.
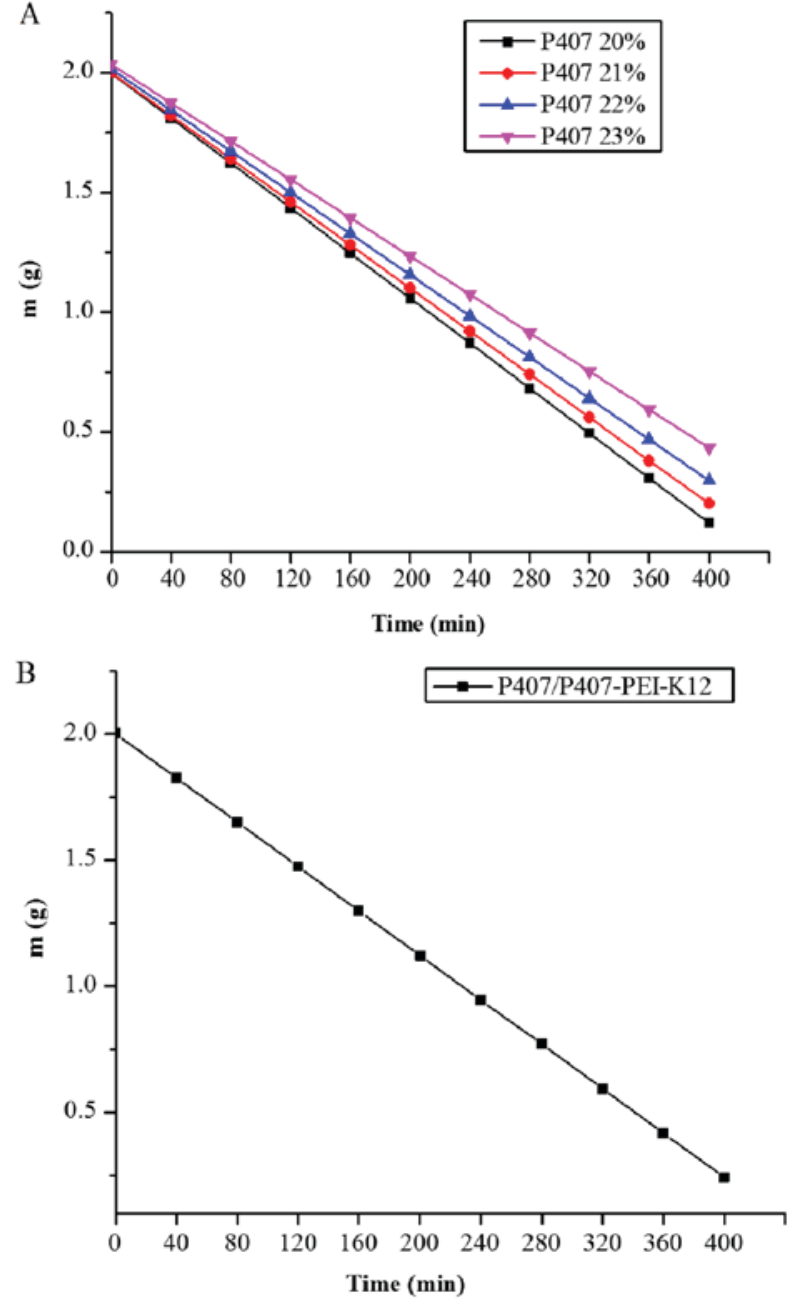

Figure 10. (A) Release of 20,21,22 and 23\% P407 gels from 0 to 400 min, using 0.1 M PBS as a solvent. (B) Release of P407/P407-PEI-K12-h/DNA complex gel from 0 to 400 min with the mass ratio of free P407 to polymer/DNA complex being 8.75:1 and the concentration of P407 in total complex solution being $21 \%$. P407, poloxomer 407; PEI, polyethylenimine.

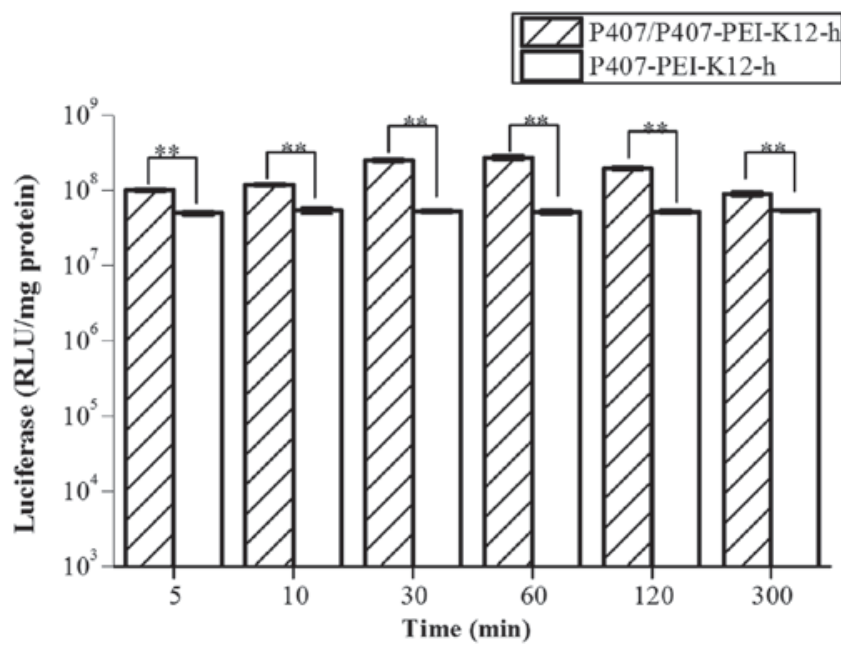

Figure 11. Transfection efficiency of P407/P407-PEI-K12-h/DNA and P407-PEI-K12-h/DNA at optimal conditions in Hela cells at various gel sustained-release times ranging from 5-300 min. The experiment was repeated six times for statistical analysis. Each data point represents the mean \pm standard deviation. $\mathrm{n}=6,{ }^{* *} \mathrm{P}<0.01$. $\mathrm{P} 407$, poloxomer 407 ; $\mathrm{PEI}$, polyethylenimine; RLU, relative light unit.

gels may provide constant release. As presented in Fig. 10B, the half-life of the P407/P407-PEI-K12-h/DNA complex gel was 228 min, similar to that of 21 and $22 \%$ free P407. The release rate of the complex gel was $4.4 \mathrm{mg} / \mathrm{min}$. Furthermore, the concentration of P407 in complex solution was $21 \%$ and the release rate of free $\mathrm{P} 407$ in polymer/DNA complex gel was $0.924 \mathrm{mg}$ per minute, which accounted for $0.09 \% / \mathrm{ml}$ of released medium and exhibited preferable transfection efficiency. The P407/P407-PEI-K12-h/DNA complex gel may meet the requirements of a follow-up study.

In vitro gene transfection of P407/P407-PEI-K12-h/DNA complex at different release times. The P407/P407-PEIK12-h/DNA complex exhibited higher transfection efficiency compared with the P407-PEI-K12-h/DNA complex at various durations of sustained release (Fig. 11). The transfection efficiency of P407/P407-PEI-K12-h/DNA complex was markedly higher compared to the P407-PEI-K12-h/DNA complex at 5-60 min under optimal conditions. The polymer in P407/P407-PEI-K12-h/DNA complex could be degraded within 60-300 min and the transfection efficiency of the P407/P407-PEI-K12-h/DNA complex was gradually decreased; however, it remained higher than the P407-PEI-K12-h/DNA complex. Therefore, when added into the P407-PEI-K12-h/DNA complex solution, free P470, a temperature-sensitive in situ gel, may not only have a good sustained release but also increase transfection efficiency, allowing stable gene expression.

In the present study, P407-PEI-K12 was synthesized by cross-linking LMW PEI with P407 and further coupling the bifunctional peptide K12. The K12 peptide has previously been demonstrated to retain its expected functionality and not be quenched by the PEI cation (26). The synthesized P407-PEI-K12 demonstrated low cytotoxicity and high transfection efficiency. The novel polymer exhibited suitable buffer capacity, with good size ranges and zeta potential, and effectively prevented the degradation of plasmid DNA 
by DNase I, with a marked ability for serum tolerance. Prior to the present study, B16, U87 and Hela cells were chosen to perform comparative transfection experiments with luciferase plasmid, in order to evaluate the transfection efficiency of P407-PEI-K12 in several tumor cells; the results demonstrated that the transfection of P407-PEI-K12 in Hela cells was the best (data not shown). Furthermore, the transfection efficiency of P407-PEI-K12-h/DNA in Hela cells was higher at a polymer and plasmid DNA ratio of 20:1 (w/w). The addition of free P407 at $0.09 \%$ to the P407-PEI-K12-h/DNA solution exhibited excellent ability for transfection and sustainable gene expression. With a mass ratio of free P407 to polymer/DNA complex of 8.75:1, the concentration of free P407 was $21 \%$, the half-life of the P407/P407-PEI-K12-h/DNA complex gel was $228 \mathrm{~min}$ and the dissolution amount of free P407 was accounted for $0.09 \%$ in the $1 \mathrm{ml}$ aliquot of release liquid, which achieved good sustained release and exhibited higher transfection efficiency. The transfection efficiency of P407/P407-PEI-K12-h/DNA complex was markedly higher than the P407-PEI-K12-h/DNA complex at various release times. In conclusion, the addition of free P407 into P407-PEI-K12-h solution may be used as a potential sustained-release gene delivery system to enhance cell transfection and prolong gene expression, which can improve the efficacy of tumor therapy in a clinical setting.

\section{Acknowledgements}

Not applicable.

\section{Funding}

This study was supported by the National Natural Science Foundation, China (grant nos. 81001024 and 81572989) and the seed fund program of Shanghai University of Medicine and Health Sciences, Shanghai, China (grant no. HMSF-17-21-014).

\section{Availability of data and materials}

The datasets used and analyzed during the present study are available from the corresponding author on reasonable request.

\section{Authors' contributions}

HS and KL designed the experiments; HS and YZ performed most of the experiments; MZ and JW analyzed the data; $\mathrm{MC}$ and JWW performed some of the experiments and were involved in drafting the manuscript; HS wrote the paper.

\section{Ethics approval and consent to participate}

Not applicable.

\section{Patient consent for publication}

Not applicable.

\section{Competing interests}

The authors declare that they have no competing interests.

\section{References}

1. Ambattu LA and Rekha MR: Collagen synthesis promoting pullulan-PEI-ascorbic acid conjugate as an efficient anti-cancer gene delivery vector. Carbohydr Polymers 126: 52-61, 2015.

2. Tripathi SK, Gupta S, Gupta KC and Kumar P: Efficient DNA and siRNA delivery with biodegradable cationic hyaluronic acid conjugates. R Soc Chem 3: 15687-15697, 2013.

3. Shen J, Zhao DJ, Li W, Hu QL, Wang QW, Xu FJ and Tang GP: A polyethylenimine-mimetic biodegradable polycation gene vector and the effect of amine composition in transfection efficiency. Biomaterials 34: 4520-4531, 2013.

4. Pérez-Martínez FC, Carrión B and Ceña V: The use of nanoparticles for gene therapy in the nervous system. J Alzheimers Dis 31: 697-710, 2012.

5. Liu K, Wang X, Fan W, Zhu Q, Yang J, Gao J and Gao S: Degradable polyethylenimine derivate coupled to a bifunctional peptide R13 as a new gene delivery vector. Int J Nanomed 7: 1149-1162, 2012.

6. Thomas M, Ge Q, Lu JJ, Chen J and Klibanov AM: Cross-linked small polyethylenimines: While still nontoxic, deliver DNA efficiently to mammalian cells in vitro and in vivo. Pharm Res 22: 373-380, 2005.

7. Wang W, Li M, Zhang Z, Cui C, Zhou J, Yin L and Lv H: Design, synthesis and evaluation of multi-functional tLyP-1-hyaluronic acid-paclitaxel conjugate endowed with broad anticancer scope. Carbohydr Polym 156: 97-107, 2017.

8. Wang HY, Chen JX, Sun YX, Deng JZ, Li C, Zhang XZ and Zhuo RX: Construction of cell penetrating peptide vectors with N-terminal stearylated nuclear localization signal for targeted delivery of DNA into the cell nuclei. J Control Release 155: 26-33, 2011.

9. Hu J, Zhao W, Liu K, Yu Q, Mao Y, Lu Z, Zhang Y and Zhu M: Low-molecular weight polyethylenimine modified with pluronic 123 and RGD- or chimeric RGD-NLS peptide: Characteristics and transfection efficacy of their complex with plasmid DNA. Molecules 21: pii: E655, 2016.

10. Kabanov AV, Lemieux P, Vinogradov S and Alakhov V: Pluronic block copolymers: Novel functional molecules for gene therapy. Adv Drug Deliv Rev 54: 223-233, 2002.

11. Amir F, Marta C and Alexander S: Thermogelling properties of purified poloxamer 407. Heliyon 3: e00390, 2017.

12. CiL, Huang Z, Liu Y,Liu Z, Wei G and Lu W: Amino-functionalized poloxamer 407 with both mucoadhesive and thermosensitive properties: Preparation, characterization and application in a vaginal drug delivery system. Acta Pharm Sin B 7: 593-602, 2017.

13. Wannis B, Vimon T, Namon H, Suppalak P and Thitima U: The effect of the preservative methylparaben on the thermoresponsive gelation behavior of aqueous solutions of poloxamer 407. J Mol Liquids 240: 622-629, 2017.

14. Cespi M, Bonacucina G, Pucciarelli S, Cocci P, Perinelli DR, Casettari L, Illum L, Palmieri GF, Palermo FA and Mosconi G: Evaluation of thermosensitive poloxamer 407 gel systems for the sustained release of estradiol in a fish model. Eur J Pharm Biopharm 88: 954-961, 2014.

15. Hamoudi-Ben Yelles MC, Tran Tan V, Danede F, Willart JF and Siepmann J: PLGA implants: How Poloxamer/PEO addition slows down or accelerates polymer degradation and drug release. J Control Release 253: 19-29, 2017.

16. Puligujja P, Balkundi SS, Kendrick LM, Baldridge HM, Hilaire JR, Bade AN, Dash PK, Zhang G, Poluektova LY, Gorantla S, et al: Pharmacodynamics of long-acting folic acid-receptor targeted ritonavir-boosted atazanavir nanoformulations. Biomaterials 41: 141-150, 2015.

17. Chung TW, Liu DZ and Yang JS: Effects of interpenetration of thermo-sensitive gels by crosslinking of chitosan on nasal delivery of insulin: In vitro characterization and in vivo study. Carbohydrate Polymers 82: 316-322, 2010.

18. M A Fathalla Z, Vangala A, Longman M, Khaled KA, Hussein AK, El-Garhy OH and Alany RG: Poloxamer-based thermoresponsive ketorolac tromethamine in situ gel preparations: Design, characterisation, toxicity and transcorneal permeation studies. Eur J Pharm Biopharm 114: 119-134, 2017.

19. Zhang FL, Jia SQ, Zheng SP and Ding W: Celastrol enhances AAV1-mediated gene expression in mice adipose tissues. Gene Ther 18: 128-134, 2011.

20. Tsoneva I, Iordanov I, Berger AJ, Tomov T, Nikolova B, Mudrov N and Berger MR: Electro delivery of drugs into cancer cells in the presence of poloxamer 188. Biomed Biotechnol 10: 1-11, 2010. 
21. Zhu M, Liu K, Zhu Q, Chen S, Lv H, Zhao W, Mao Y and $\mathrm{Hu} \mathrm{J}$ : Intracellular disassembly and localization of a new P123-PEI-R13/DNA complex. Biomed Mater Eng 24: 1925-1931, 2014.

22. Pujari-Palmer S, Chen S, Rubino S, Weng H, Xia W, Engqvist H, Tang L and Ott MK: In vivo and in vitro evaluation of hydroxyapatite nanoparticle morphology on the acute inflammatory response. Biomaterials 90: 1-11, 2016.

23. Ma K, Hu MX, Qi Y, Zou JH, Qiu LY, Jin Y, Ying XY and Sun HY: PAMAM-Triamcinolone acetonide conjugate as a nucleus-targeting gene carrier for enhanced transfer activity. Biomalerials 30: 6109-6118, 2009.

24. Kim TH, Cook SE, Arote RB, Cho MH, Nah JW, Choi YJ and Cho CS: A degradable hyperbranched poly(ester amine) based on poloxamer diacrylate and polyethylenimine as a gene carrier. Macromol Biosci 7: 611-619, 2007.
25. Dewan M, Sarkar G, Bhowmik M, Das B, Chattoapadhyay AK, Rana D and Chattopadhyay D: Effect of gellan gum on the thermogelation property and drug release profile of Poloxamer 407 based ophthalmic formulation. Int J Biol Macromol 102: 258-265, 2017.

26. Zhang M, Hu J, Zou Y, Wu J, Yao Y, Fan H, Liu K, Wang J and Gao S: Modification of degradable nonviral delivery vehicle with a novel bifunctional peptide to enhance transfection in vivo. Nanomedicine (Lond) 13: 9-24, 2018.

(i) () This work is licensed under a Creative Common Attribution-NonCommercial-NoDerivatives 4.0 International (CC BY-NC-ND 4.0) License. 